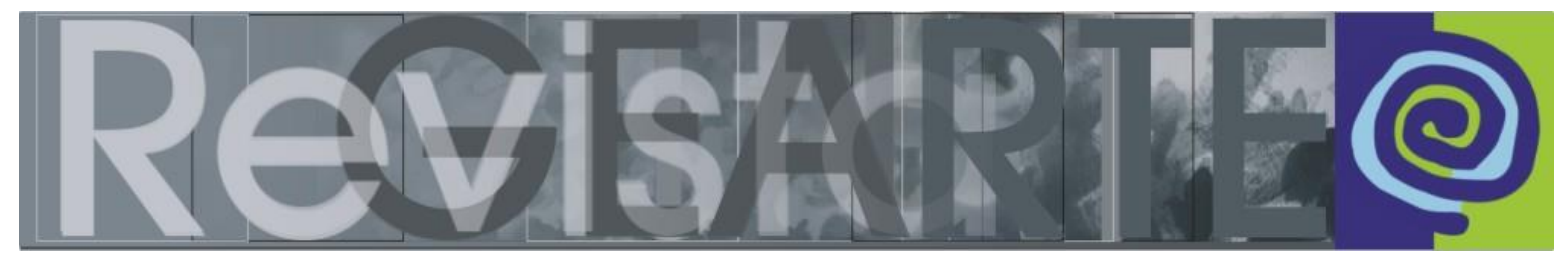

Volume 1, Número 2, Agosto/2014, ISSN 2357-9854

\title{
Mediações culturais e contaminações estéticas
}

\author{
Mirian Celeste Martins (MACKENZIE - Brasil)
}

\section{RESUMO}

Mediação, uma palavra-valise, carregada de significações. Junte-se a ela outra palavra - cultura, e tem-se um baú de significações que perpassam por diversos conceitos e atuações. Cientes da diversidade e da riqueza dos múltiplos olhares possíveis a este emaranhado e complexo conteúdo, nos debruçamos para pinçar algumas de suas dimensões. Talvez o âmago desta proposição esteja conectado à busca de objetivos: Por que mediamos? Para ensinar arte ou para propor encontros significativos com ela? Pode a mediação cultural ser compreendida como contaminação estética? Estas são inquietações que atravessam o Grupo de Pesquisa "Mediação cultural: contaminações e provocações estéticas". Neste artigo, parte-se de "medicações poéticas" para iniciar uma conversa silenciosa com o leitor. Virus, memes e contaminações desatam os fios que movem a pesquisa e se revelam na construção do livro "pensar juntos mediação cultural: [entre]laçando experiências e conceitos" (2014). Apresenta também uma leitura dos principais termos presentes no índice remissivo que evidenciam um modo de pensar a medição cultural como ação e não como função. Uma advertência ao leitor: "Agite-se antes de ler".

\section{PALAVRAS-CHAVE}

Mediação cultural; contaminação estética; arte; acesso cultural.

\section{ABSTRACT}

Mediation, a word-valise, full of meanings. Affiliate with another word - culture, and it has a chest of meanings that permeate by various concepts and actions. Awareness of the diversity and richness of multiple possible looks to this tangled and complex content, worked through us to pinch some of its dimensions. Perhaps the heart of this proposition is connected to the pursuit of goals: Why we use mediation? To teach art or to propose meaningful encounters with her? Could be considered mediation as an aesthetic contamination? These are concerns that cross the Research Group "Cultural Mediation: aesthetic contaminations and provocations". In this article, it is part of "poetic medications" to start a silent conversation with the reader. Virus, memes and contamination untie the cords that move the research and are revealed in the book building "think together cultural mediation: interlacing roping experiences and concepts" (2014). It also presents a reading of key terms present in the index tab that have a way of thinking about cultural measurement as action rather than function. A warning to the reader: "Shake before you read."

\section{KEY WORDS}

Cultural mediation; aesthetic contamination; art; cultural access.

Figura 3 - Zeca Baleiro. Maldição, 2010.
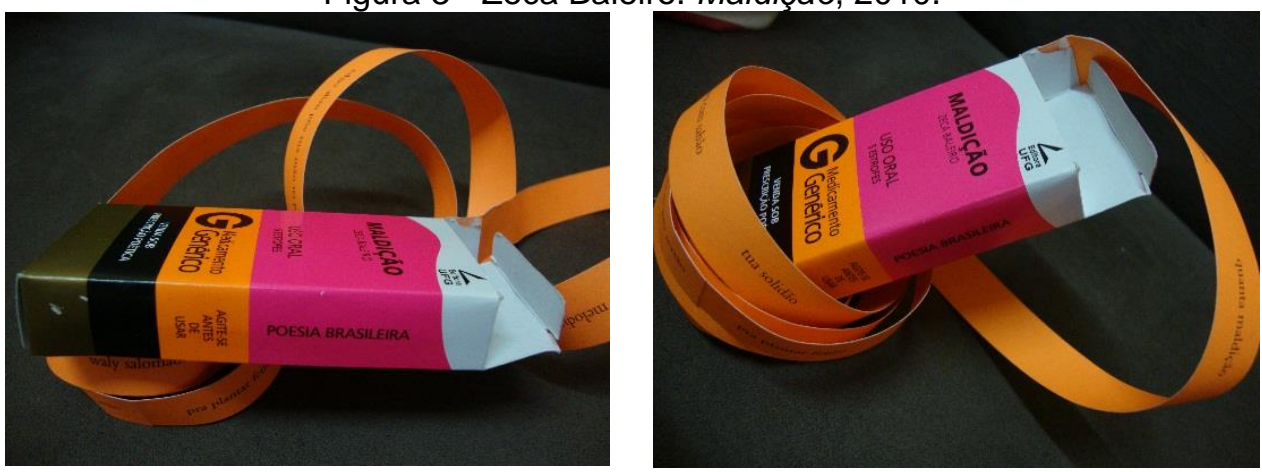

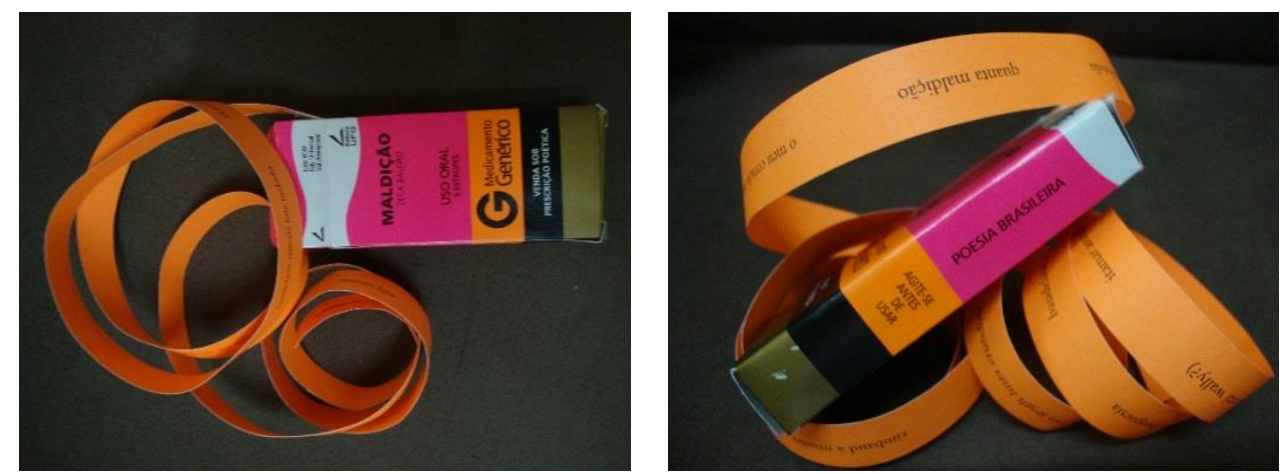

Foto: Maristela Rodrigues.

O medicamento é genérico, mas a tarja preta afirma: "Venda sob prescrição poética." E avisa: "Agite-se antes de usar." Dentro uma longa tira que se desenrola e nos traz o poema Maldição e na primeira estrofe: "Baudelaire, Macalé, Luiz Melodia/ Quanta maldição / o meu coração não quer dinheiro quer poesia” (BALEIRO, 2010).

A caixa de remédio faz parte de uma caixa acrílica, um song-book que pode ser considerado um livro-objeto - Vida é um Souvenir Made in Hong Kong, lançado em 2010. Foi produzido pela Editora da Universidade Federal de Goiás, dentro da Coleção Artexpressão e tem como ilustrador Roger Mello.

Gotinhas de "memes culturais" ou de "vírus estético" e balinhas "Monitorex" foram ideias lançadas por Gisa Picosque e por mim nas parcerias em coordenações de ações educativas para a Mostra do Redescobrimento (2000), 25 Bienal Internacional de São Paulo (2002), 4⿳亠丷 Bienal do Mercosul (2004), entre outras. Eram oferecidas para as equipes, na ludicidade da motivação e estímulo para o trabalho de mediação.

Muito antes, Fanny Abramovich, Márcia Mathias e Chaké Ekizian (1979), lançaram o livro Teatricina que vinha acompanhado de um vidro com comprimidos. Na capa se lê: "Via total - 45 cápsulas em 5 cap. Venda sem controle escolar". A diagramação é provocadora e foi criada por Marcelo e Milton Cipis. A bibliografia vem em forma de receita da Clínica ludo-pedagógica com as indicações terapêuticas: "Tomar um comprimido literário ao dia e um comprimido visual ou sonoro à noite" (ABRAMOVICH et al., 1979, s/p) com a data de maio de 1975.

Há em todos estes "medicamentos" uma proposição comum: levar de fora para dentro algo que mova cada sujeito para o mergulho nas sensações, na percepção 
sensível, no agitar de todos os sentidos e em todos os sentidos do corpo que também pensa e se expressa. E, puxar de dentro, a potencialidade e abertura para encontros com a arte e a cultura. Assim, não precisamos nos apavorar com mais um vírus, mais uma contaminação em tempos de possíveis epidemias. Aqui o vírus é outro, um tipo que contamina esteticamente e modifica aquele que nutre e aumenta o vigor para perceber e transitar no mundo - uma saudável contaminação, e mais do que isso, necessária...

É esta a conversa deste texto que nasce do desejo de buscar [con]tato com o leitor, mesmo em diálogos silenciosos. Portanto, fica aqui o aviso: Agite-se antes de ler!

\section{De memes, vírus e contaminações, de funções e ações}

1992. Descoberto o "vírus estético" no laboratório de formação de professores - Espaço Pedagógico, um feliz lugar compartilhado com Madalena Freire, Juliana Davini e Fátima Camargo onde aprendemos muito, na ousadia de pensar arte, pedagogia, psicanálise entre 1992 e 2004. O texto com certo humor, divulgado apenas internamente, foi escrito como uma descrição científica, apontando a descoberta pela professora-aluna Pnina Friedlander: sua composição e desenvolvimento, seus sintomas e recomendações.

Como parte da herança genética de todo e qualquer animal simbolicum tendo como referência Cassirer (1977) —, o vírus estético apresentava dois fatores: Rh e Rc. Dizia o texto:

O fator Rh vincula-se aos recursos dos humanos que interagem com 0 portador do vírus. O educador tem um papel primordial como facilitador e instigador para a proliferação do vírus. Entretanto, um educador ineficiente pode atrapalhar o desenvolvimento e até barrar, temporariamente, a sua evolução. Em circunstâncias externas não favoráveis, a proliferação do vírus depende do Rh interno, capaz de criar anticorpos eficientes contra a ação indesejada. O fator $R c$ vincula-se aos recursos da cultura onde o indivíduo e seu vírus habita. Nele estão inseridos os sub-fatores: tempo e lugar. [...] A medicação aconselhada para revitalização destes fatores é a contaminação de reforço. Viagens, visitas a museus, galerias, audição de concertos ou de discos (sic), presença em apresentações de teatro, de dança, contatos com livros, revistas, são alguns possíveis reforços. A presença de um instigador como mediador que desafia para a leitura e produção artística/estética é vital para que a medicação seja eficiente (MARTINS, 1992, p.2). 
Como facilitador e instigador para a proliferação do tal vírus estético, o educador era considerado primordial, assim como os anticorpos eficientes contra atitudes que afastam, contra preconceitos ou modelos direcionados, contra o pensamento simplista.

Foi em 2001, que as referências se ampliaram com Helena Katz no curso de formação de educadores para a exposição Parade - 1901-2001 realizada na Oca, no Parque do Ibirapuera, apresentando-nos o conceito de meme. Seu autor, o biólogo e etólogo Richard Dawkins (2001, p. 221) afirma: "Quando morremos há duas coisas que podemos deixar atrás de nós: genes e memes". Gene é a unidade de transmissão genética. Como máquinas gênicas, nos esquecemos dessa transmissão em três gerações: pouco sabemos sobre o que herdamos fisicamente de nossos tataravôs, por exemplo. Por outro lado, os memes são unidades de transmissão cultural. As ideias se propagam de cérebro em cérebro, por contaminação, e são replicadas e transformadas por nossas próprias maneiras de compreendê-las e operar com elas. Eu nem poderia suspeitar que, mais de uma década depois, os memes-mensagens tomariam conta das redes sociais, seriam compartilhados e se espalhariam com uma velocidade incrível. Memes que desaparecem? Memes potentes que geram um número enorme de compartilhamentos? O que ficará deles? Publicidade viral, a impulsionar o consumo?

As palavras podem ser perigosas, o remédio pode fazer mal, mas vírus e memes foram tecendo a ideia de contaminações estéticas que juntamente com o ato de provocar nomeiam o Grupo de Pesquisa "Mediação cultural: contaminações e provocações estéticas". O início se deu em 2003, no Instituto de Artes da Universidade Estadual Paulista "Júlio de Mesquita Filho" (UNESP), onde o primeiro grupo foi criado - Mediação arte/cultura/público. Lá se encerrou em 2007, mas continuaram conosco sete integrantes deste primeiro grupo ${ }^{1}$ reiniciado em 2009 em nova casa: a Universidade Presbiteriana Mackenzie, onde se somam novos integrantes ${ }^{2}$.

\footnotetext{
1 Integrantes do Grupo de Pesquisa Mediação arte/cultura/público do IA/UNESP que continuam conosco na UPM: Maria de Lurdes Souza Fabro; Maria José Braga Falcão; Maria Lucia Bighetti Fioravanti; Maristela Sanches Rodrigues; Olga Egas; Rita de Demarchi e Solange Utuari.

2 Outros integrantes do grupo que junto com os citados na nota anterior participaram da construção e escrita do novo livro: Ana Carmen Nogueira; Bruno Fisher Dimarch; Célia Cristina Rodrigues De
} 
Várias foram as pesquisas e estudos realizados pelo grupo, e dissertações apresentadas, mas uma ideia que nasceu no almoço de final de ano em 2011, no restaurante do MASP, atravessou o tempo em um longo e intenso processo e se concretizou em 2014: um novo livro - pensar juntos mediação cultural [entre]laçando experiências e conceitos. Na sua introdução, apresentamos as três perguntas que animaram sua estrutura que foi composta inicialmente pelas palavras coloridas de cada um nos textos colaborativos que têm marcado nossa história: A qual público se destina? Por que queremos escrevê-lo? Como escrevê-lo?

No coração das perguntas estava o desejo de contato com o leitor. Queríamos tornar o livro um objeto propositor, inspirados no desejo de sermos propositores, pois como dizia Ligia Clark (1968): "[...] nossa proposição é o diálogo. Sós, não existimos. Estamos à sua mercê. Nós somos os propositores: enterramos a obra de arte como tal e chamamos você para que o pensamento viva através de sua ação."

Ação! Um livro para trilhar, movido pelas próprias inquietações, saberes e curiosidade. Uma possível ação poética do leitor e uma possível ação mediadora. $\mathrm{E}$ aqui, abre-se uma distinção entre a função e ação e o modo como vemos a mediação cultural.

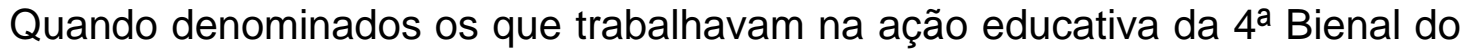
Mercosul como "mediadores", confundimos a função com a ação, pois não podemos dizer que todos fizeram mediações no sentido que o termo tem ganho para nós. Não basta atuar no setor educativo de uma instituição cultural ou em uma escola para ser mediador... Interessa-nos as ações mediadoras percebendo seus matizes e a potência para gerar encontros com a arte e a cultura.

É preciso pensar a diferença entre apresentação, explicação, interpretação, conhecimento teórico, informação e mediação cultural. Embora essas ações se superponham em alguns momentos, ver diferenças pode nos ajudar a distingui-las. Em síntese, poderíamos dizer que apresentar uma obra é como introduzir um texto, como colocar alguém frente a algo (um autor, uma obra, uma técnica). Em algumas mediações a apresentação é feita depois ou em meio a conversa. A explicação, por

Donato; Daniela Souza Martins; Estela Maria Oliveira Bonci; Francione Oliveira; Jorge Wilson da Conceição e Marcia Polachini de Oliveira. 
outro lado, é entendida por Rancière (2010, p. 22) como uma prática embrutecedora que desconhece a distância entre o que quer ensinar e o sujeito, entre o aprender e o compreender: "O explicador é aquele que impõe e abole a distância, que a desdobra e que a reabsorve no seio de sua palavra". Não há perguntas ou interpretações à explicação do explicador. Há apenas a repetição da explicação que se encerra em si. É muito diferente da informação quando dosada, adequada para quem a ouve, simples, mas não simplista tornando-se uma boa chave de leitura que se abre a novas conexões. Mas é preciso cuidado, pois o excesso de informação pode não deixar lugar à experiência. Alerta Larrosa (2004, p. 155): "Não deixa de ser curiosa a intercambialidade entre os termos 'informação', 'conhecimento' e 'aprendizagem'. Como se conhecimento se desse sob o modo da informação e como se aprender não fosse outra coisa que adquirir e processar informação".

A interpretação é uma outra ação. Segundo Luigi Pareyson (1989, p. 167), ela é "[...] um encontro entre um dos infinitos aspectos da forma e um dos infinitos pontos de vista da pessoa". Entre os múltiplos aspectos e pontos de vista, qual o espaço para que as interpretações pessoais aconteçam? Ou oferecemos a interpretação do curador, ou de um historiador, ou de um filósofo, ou...? O problema não é lidar com muitas interpretações, inclusive as que se opõem, mas considerar e apresentar apenas uma como a certa e única.

Cada vez mais fica visível o modo como temos trabalhado com o conceito de mediação cultural, como ação e não como função. Afinal, mediamos para "ensinar arte" ou para propor encontros significativos com ela? Mediação como contaminação estética?

\section{De fios e nuvens em movimento}

Os caminhos de nossas pesquisas foram sendo construídos alargando o grande continente da mediação, considerando os territórios de fronteiras porosas e os estudando a partir das próprias experiências com a arte. Impulsionados pela oportunidade de aproximarmos nossos estudos de outros nos congressos, escrevemos artigos sempre de modo colaborativo, nas reuniões presenciais e em discussões via internet - por e-mail e Skype, nas quais cada um vai marcando a sua interação com uma cor diferente no arquivo em Word, gerando textos que 
amadurecem com a somatória de várias cores/vozes do grupo. É o que aconteceu com o artigo: "Mediação cultural expandindo conceitos entre territórios de arte \& cultura" para o ConFAEB 2011 em São Luiz/MA e "Mediação cultural entre territórios de arte\&cultura" para o Congresso na UNESP em Águas de Lindóia/SP também em 2011.

Figura 4 - Cartografia dos territórios de arte\&cultura.

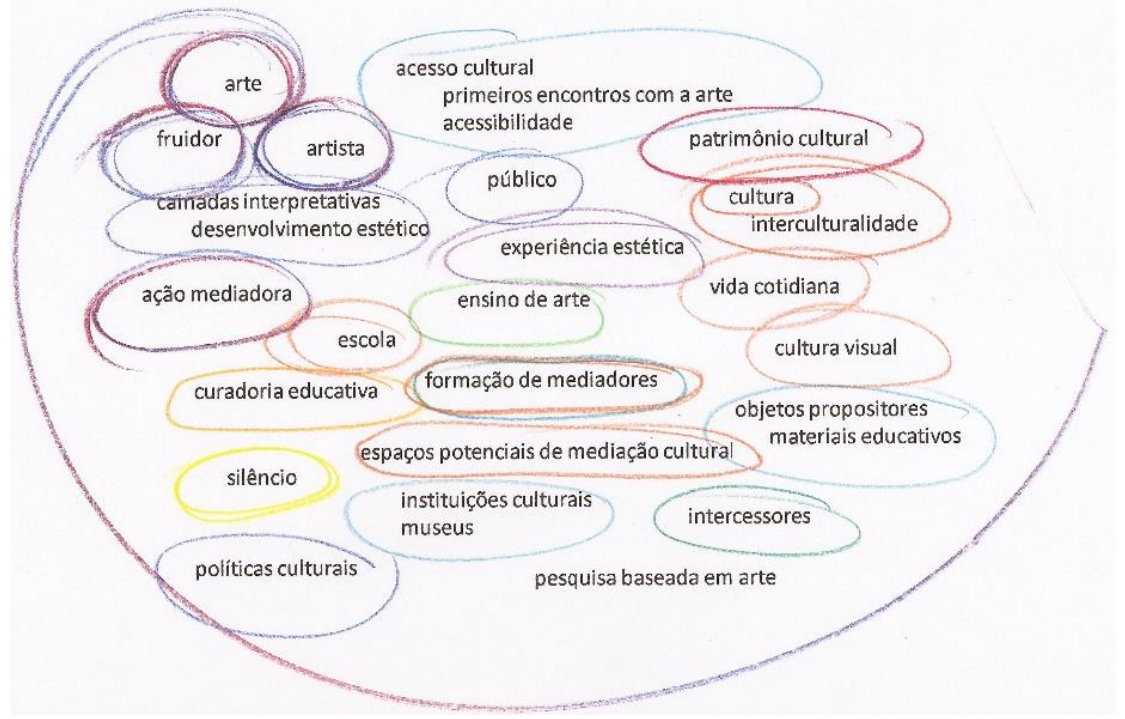

Fonte: arquivo pessoal da autora

Territórios porosos que se superpõe e se conectam, desterritorializam-se e recriam outros territórios ${ }^{3}$, como rizomas em constante mutação (DELEUZE E GUATARRI, 1995). Para alguns pode parecer uma fragmentação, mas todos os territórios fazem parte de um todo. Apontam diferenças, muitas vezes sutis, campos difusos de fronteiras e de bordas evanescentes. Os territórios formam uma grande cartografia: Ação mediadora; Acessibilidade cultural; Cultura visual; Curadoria Educativa; Desenvolvimento estético; Espaços expositivos na escola; Formação docente; Leitura de imagem: metodologias; Leitura de imagens: camadas interpretativas; Mediação cultural nos museus e instituições culturais; Objetos propositores; Patrimônio Cultural; Políticas e Produção cultural; Provocações e contaminações estéticas; Recepção; Silêncios; ...

\footnotetext{
${ }^{3}$ Territórios começam a ser estudados mais recentemente, como a pesquisa baseada em arte, um território que se liga à mediação cultural por fendas em que temos penetrado com mais intensidade nos últimos tempos, mas que ainda é uma dimensão para mergulhar, embora a arte sempre esteve alimentando nosso pensar, como as obras que aqui estão a dizer conosco.
} 
Ao resgatar as premissas, ações e os movimentos que empreendemos para fazer o livro, que foi uma provocação para nós mesmos por três anos, destacamos que os territórios se tornaram em nossos estudos fontes de estudo a partir das nossas próprias experiências com a arte. Assim, na memória de nossas vidas, fomos vendo o que nos contaminou nos encontros com a arte e deles fomos extraindo os conceitos. Uma cartografia criada em 2012 revela as conexões entre territórios e memórias pessoais:

Figura 5 - Cartografia do livro realizada em 2012 interligando territórios de arte\&cultura e as memórias pessoais.

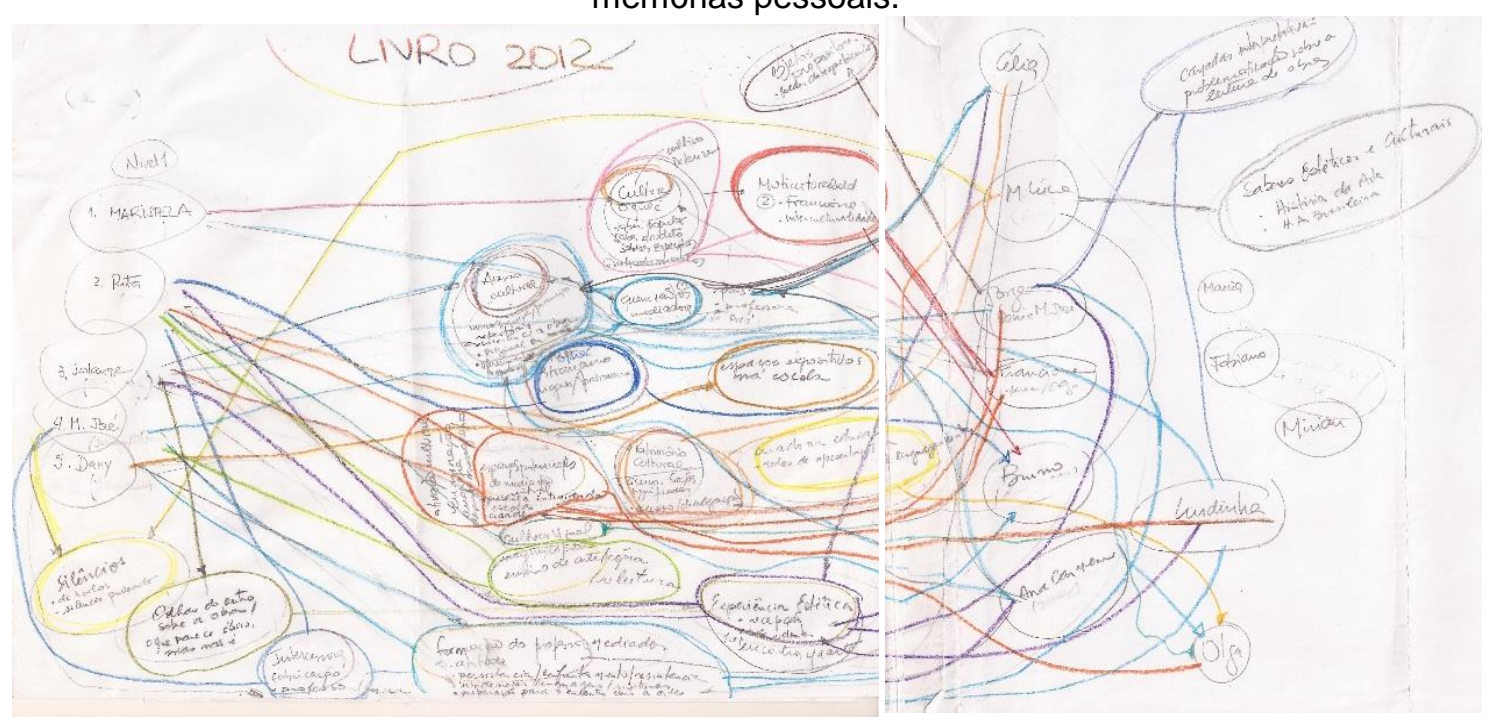

Fonte: arquivo pessoal da autora

A nossa cartografia se conecta com a obra Penélope, de Tatiana Blass ${ }^{4}$, que revela o mito grego e a espera amorosa. Potência em cada fio que pode gerar tecidos diversos. Potência da obra dando a ver o conceito que nos alimenta.

\footnotetext{
${ }^{4}$ Penélope de Tatiana Blass esteve na Capela do Morumbi na cidade de São Paulo entre setembro de 2011 e abril de 2012. Um tapete vermelho de quatorze metros vai da porta de entrada da Capela até um grande tear manual de pedal localizado próximo ao altar, onde sua urdidura está presa. Os fios saem do outro lado do tear em grande quantidade, caem pelo chão e passam pelos buracos das paredes de taipa. Assim, os fios vermelhos invadem o verde do jardim do museu.
} 
Figura 6 - Tatiana Blass. Penélope , 2011. Capela do Morumbi.

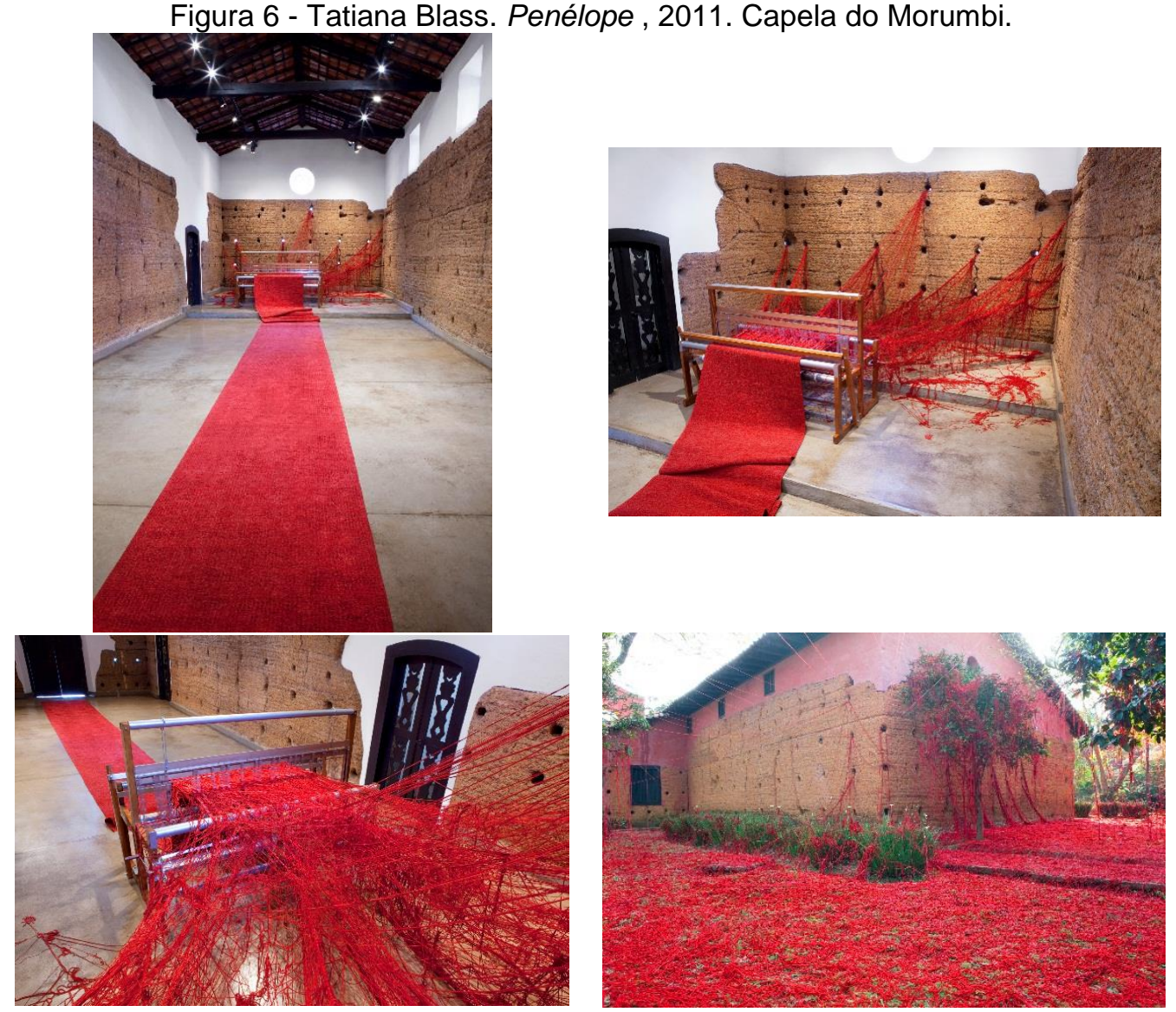

Foto: Everton Balardin

E, assim, foi se construindo o livro, focalizando a mediação com a cultura, entendida como um campo expandido para experiências estéticas, em fios que vão se conectando em todos os sentidos. No aspecto formal, os fios se materializam nas publicações organizadas por mim, sempre com felizes parcerias. Fios que eram brancos em Mediação: provocações estéticas (2005), eram vermelhos e amarrados pelo leitor em Mediando [con]tatos com arte e cultura (2007), eram imagens em Mediação cultural para professores andarilhos na cultura (2012). Agora - pensar juntos mediação cultural: [entre]laçando experiências e conceitos (2014) - são barbantes e fios de estopa que magicamente brincam de nuvens encapsuladas em capas de CD, na mágica sensível do artista Alcindo Moreira Filho. 
Figura 7 - Alcindo Moreira Filho, Entrenuvens, 2013. 475 embalagens de CDs com estopa e algodão.

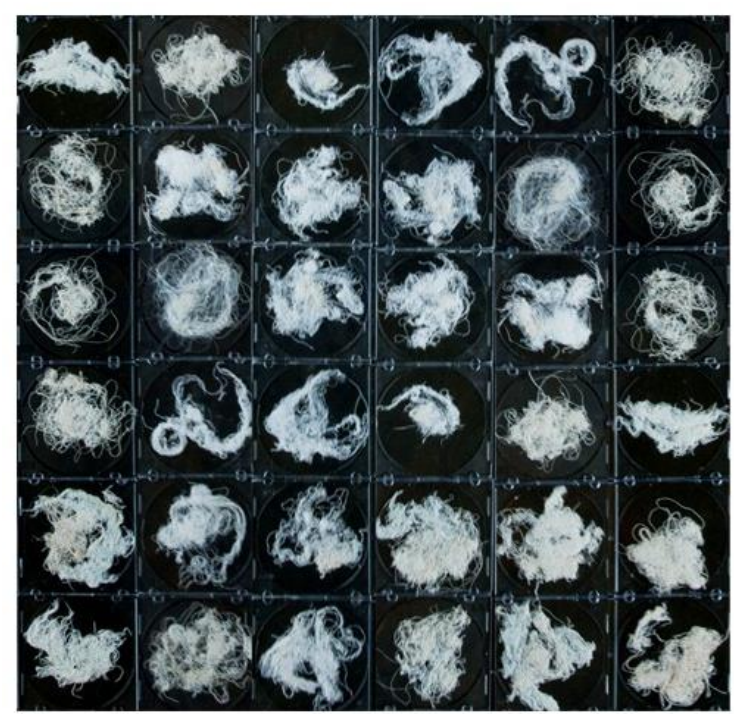

Fonte: arquivo pessoal da autora

Nuvens. Damish (apud ALPHEN, 2006) escreve entre barras - /nuvem/ compreendida como signo e não como elemento realista, pois a vê como uma espécie de "dobradiça", que une, que abre e fecha. E, também, uma nuvem de conceitos que pode nos mostrar alguns aspectos que tecem o conceito de mediação cultural.

Como pesquisadores, mapeamos todos os conceitos que apareciam nos textos, não simplesmente as palavras em meio ao texto, e com eles foi sendo laboriosamente construído um índice remissivo. Após o livro finalizado, foi uma surpresa para nós a nuvem de conceitos composta a partir dele. 
Figura 8 - Nuvens de conceitos a partir do índice remissivo

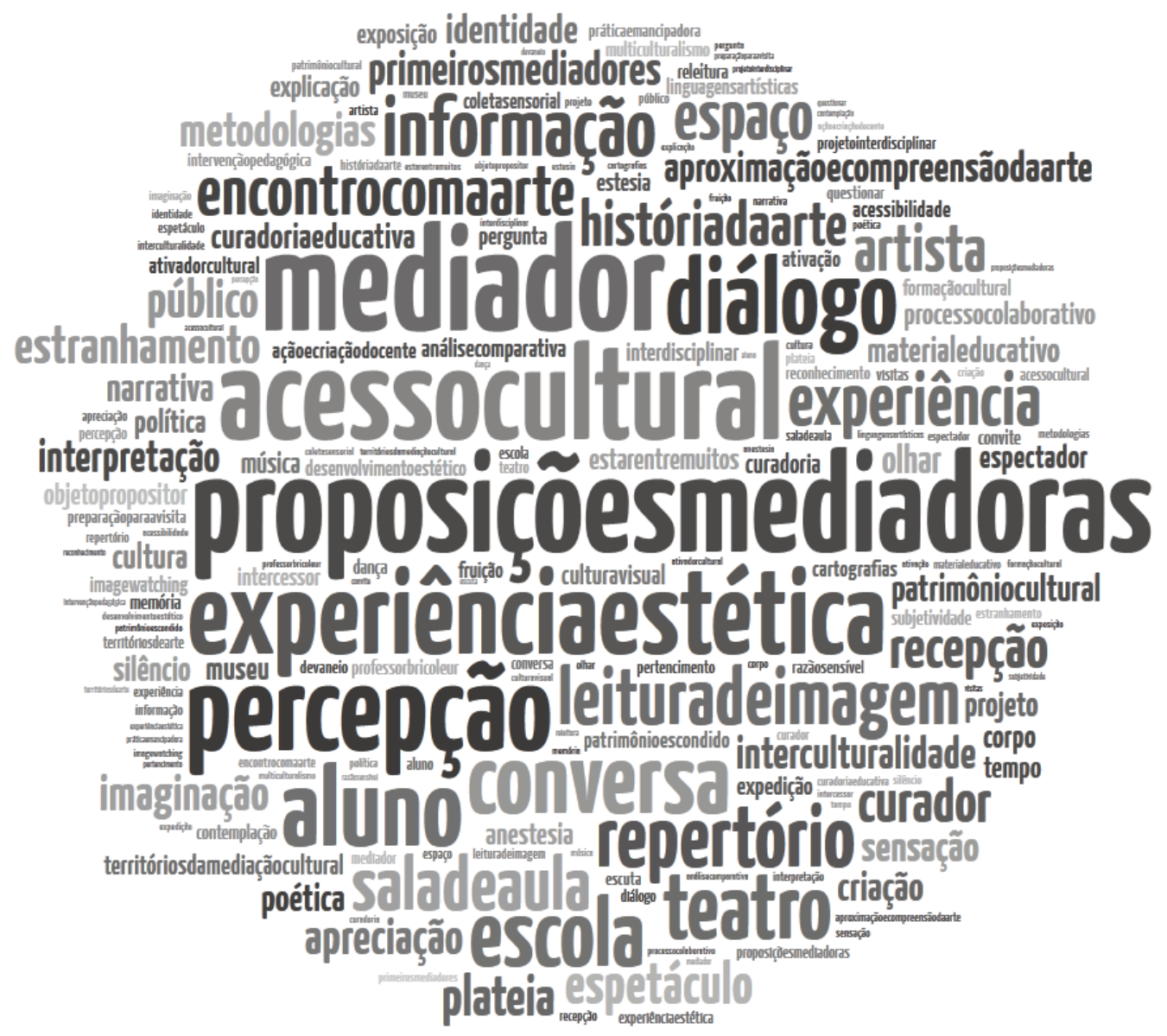

Fonte: arquivo pessoal da autora

Palavras-conceitos. Palavras-ações. O tamanho das palavras está relacionado com o número de vezes que a palavra foi selecionada para o índice por ampliar o conceito e não apenas como parte de um texto.

Palavras-chave. Elas desvelam o que, de algum modo, já suspeitávamos e foi confirmado: o coração da mediação cultural para nós, isto é, o que consideramos como os de maior relevância e que podem ser melhor lidas se as pinçarmos da nuvem de conceitos: 
Figura 9 - Palavras-chave retiradas das nuvens de conceitos a partir do índice remissivo.

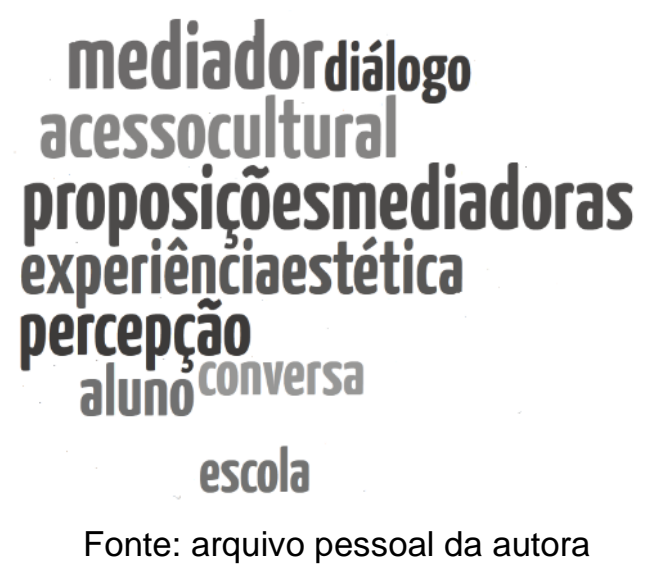

Mediador. É um dos grandes destaques. Nessa palavra estão contidos os termos: professor e educador. É ele que contamina? Tem de ser cuidadoso para não afastar e anestesiar o sujeito da experiência estética. Elemento propulsor, como um gatilho a disparar convites para o encontro com a arte. Media quem? O aluno, que contém em si os termos: aprendiz da arte, estudante, criança, adolescente, com toda a sua singularidade, seu repertórios, preconceitos e desejos.

Acesso cultural. Desde os primeiros mediadores que ofereceram encontros com a arte, sejam os pais, os avós, os tios, os professores, entre outros, o acesso cultural espelha políticas culturais e educacionais e as oportunidades que a vida oferece. Acreditar e lutar pelo acesso cultural abre espaços para experiências estéticas que se interligam com a percepção, pois, até independentemente do mediador, a arte e a cultura são mediadores por si mesmos. Contaminam muitos. Para isso, não basta apenas "curtir" no Facebook, mas comentar o que assistiu ou viu, divulgar espetáculos, concertos, exposições e intervenções em conversa na escola, no trabalho, em todos os lugares, são oportunidades de alardear e provocar contaminações estéticas.

Proposições mediadoras. Aqui se revela a nossa preocupação em tornar a mediação cultural não apenas um pensar sobre as relações entre sujeitos e a arte, mas ampliar a ação mediadora como proposições, no mesmo sentido que fez nascer o livro. Proposições que se ligam a ação do diálogo, da conversa, que pressupõem a escuta, o espaço do silêncio, a aproximação cuidadosa e sensível com o outro. 
Não há receitas de uma boa mediação cultural, pois a arte é um "bloco de sensações e, isto é um composto de perceptos e afectos. [...] A obra de arte é um ser de sensação, e nada mais: ela existe em si", dizem Deleuze e Guattari (1992, p. 213). É acertada a afirmação de Agnaldo Farias (2007, p. 67):

[a mediação] empregada como fator de aproximação, pode ser problemática, especialmente quando ela, no afã de estabelecer a ponte entre a obra e o público, incorre em estratégias simplificadoras, trai exatamente aquilo que pretende defender. Ora, a mediação não pode incorrer na simplificação do processo que se estabelece entre público e obra, não pode pretender reduzir a complexidade do trabalho que está sendo apresentado. Ela tem que garantir que a obra seja apresentada em toda a sua plenitude, fruída da melhor maneira possível.

Mais do que ponte, ela exige de nós, na ação de mediar, um consciente estado de vigília no "estar entre muitos", conceito presente em vários de nossos textos. Entre os "muitos", temos aprendido também com os artistas:

O ato criador não é executado pelo artista sozinho; o público estabelece o contato entre a obra de arte e o mundo exterior, decifrando e interpretando suas qualidades intrínsecas e, desta forma, acrescenta sua contribuição ao ato criador (DUCHAMP, 1975, p. 74).

Nesse sentido, nossa tarefa é oferecer meios para que cada sujeito que participa de uma ação mediadora possa criar, e que sua criação alimente a criação de todos, construindo diálogos que permitam esta ampliação de pontos de vista que tanto enriquece. Talvez seja esta a intenção que se coloca nas palavras do artista que nos implica na sua obra:

Ao integrar o espectador, ou, melhor, o ato mesmo de olhar como parte da tarefa do museu, o interesse se transladou da coisa experimentada à experiência em si. Ponhamos em cena os artefatos, mas o que é mais importante, ponhamos em cena o modo como se percebem os artefatos (ALIASON, 2012, p. 24-25).

Um convite para vermos vendo, sentirmos sentindo, percebermos pensando. Assim, afirma o artista:

Invertamos o ponto de vista: o museu como sujeito, o espectador como objeto. Como uma paisagem, o museu também é um constructo; apesar de seu papel global e de largo alcance como verdadeiro mito, em realidade pode ter um potencial social. Ver-se sentindo (idem).

Um potencial social na percepção de algo maior, mas que reverbera em cada um de nós. Assim, não mediamos apenas a obra de arte, mas o que está por atrás 
dela seja como acervo do museu, uma exposição temporária ou uma intervenção urbana, por exemplo e o que está na frente dela, nos percebendo visitantes turistas ou peregrinos como estuda Rita Demarchi em seu doutorado em processo de finalização.

A presença dos artistas com projetos pedagógicos aparecem desde a primeira metade de 2000, segundo Claire Bishop (2012):

\begin{abstract}
artistas e curadores tem se comprometido de modo crescente com projetos que apropriam dos temas da educação como método e forma: conferências, seminários, bibliotecas, salas de leitura, publicações, ateliês e inclusive escolas completas.
\end{abstract}

Nas andanças recentes, temos visto mudanças nos espaços educativos em diferentes instituições. A Casa Daros, no Rio de Janeiro, tem como seu slogan "Arte é educação", o Museu de Arte do Rio (MAR), criou espaços do olhar de forte ação educativa; a Pinacoteca de São Paulo, criou intervenções no espaço expositivo e um espaço educativo que provoca diálogos entre obras expostas; em Inhotim, a arte e o meio ambiente se conectam.

Percebe-se uma mudança que vai se estabelecendo, inclusive com a percepção de que os espaços potenciais de mediação cultural não são apenas os convencionais ou a cidade. A escola também pode ser um polo cultural. Fabíola Cirimbelli B. Costa (2013, p. 275), em 1997 criou o Espaço Estético do Colégio de Aplicação da Universidade Federal de Santa Catarina (UFSC):

\footnotetext{
[...] como um espaço de passagem e, quem sabe, fosse tomando corpo espalhando-se pela escola inteira e instalando-se em cada ser. [...] transformando-os em lugares quentes e vivos, os quais, tendo em conta o ponto de vista móvel, são antes mais possibilidades do que limites.
}

Consideramos que a ação mediadora não se dá apenas com boas propostas; também se dá com materiais educativos, com objetos propositores, com um bom site, com uma boa formação dos educadores que atuam, com uma equipe acolhedora, envolvendo desde o profissional que atende os telefonemas para agendamento. Dáse em cada visita e conversa, essas que aproximam ou afastam os visitantes. E na escola, do mesmo modo, cabe ao professor favorecer acesso cultural, construir curadorias educativas que ampliem o repertório de seus alunos oferecendo acesso 
não só à arte, mas também ao patrimônio cultural. Encontros capazes de contaminar os alunos como seres da cultura?

\section{Prescrição poética: uso prolongado}

Uma última inquietação, mais do que uma conclusão. No último Exame Nacional do Ensino Médio (Enem) em novembro de 2014, a redação ${ }^{5}$ teve como tema: "A publicidade infantil em questão no Brasil". Mais de 8,7 milhões de inscritos em todo o Brasil refletiram sobre a questão, muitos talvez pela primeira vez. Os textos de apoio se conectavam com uma resolução política, uma imagem de um mapa situando a questão no mundo e um texto sobre marketing que apresentava um viés educativo, apontando a necessidade de preparar a criança para compreender o que está atrás da divulgação de produtos. De certo modo, foi um tema inesperado...

Um aluno que é um "ser ativo da cultura, que sofreu a contaminação estética que carrega o vírus da "Maldição" de gostar de poesia como Zeca Baleiro, que lê imagens, percebe e interpreta signos teria mais facilidade para criar um texto dissertativo-argumentativo? Em que sentido encontros com a arte, com a cultura visual, com o patrimônio cultural, com a vida contemporânea teriam sido alimento para a redação? Ou, eles, os jovens, teriam dificuldades de ler e tecer pensamentos críticos às criações publicitárias e às coisas do mundo porque não viveram uma experiência de leitura para além das rasas releituras, biografias de artistas e reconhecimento de estilos?

Este pode ser um exemplo vívido da importância da mediação cultura e do profundo [con]tato com a dimensão estética, não apenas nos museus e instituições culturais, também nas aulas de Arte - Artes Visuais, Dança, Música, Teatro, nas aulas de História, de Literatura na escola. A mediação cultural, compreendida nos termos e problematizações que debatemos ao longo dessa reflexão, contribuiria para uma leitura mais sensível, ampla, atenta e crítica do mundo? Pensamos que talvez esta seja a brecha, o desvio para que a anestesia não embote o que temos de mais

\footnotetext{
${ }^{5}$ Redação do ENEM. Disponível em: <http://g1.globo.com/educacao/enem/2014/noticia/2014/11/temada-redacao-do-enem-sobre-publicidade-infantil-no-brasil.html>. Acesso em 12 nov 2014.
} 
humano. E que juntos, cada qual com a sua experiência, possamos provocar contaminações estéticas e continuar a tecer e conectar nuvens.

A prescrição poética não tem contraindicações. A tarja é branca. Recomendase apenas: Agite-se antes de usar!

\section{Referências}

ABRAMOVICH, Fanny, MATHIAS, Márcia F. e EKIZIAN, Chaké. Teatricina. Rio de Janeiro: Mec. Serviço Nacional do Teatro, 1979.

ALPHEN, Ernest V. Lances de Hubert Damisch: pensando a arte na história. Revista PPGAV Programa de Pós-Graduação em Artes Visuais da Escola de Belas Artes da Universidade Federal do Rio de Janeiro. Rio de Janeiro, p. 93-103, 2006. Disponível em: <http://www.ppgav.eba.ufrj.br/wpcontent/uploads/2012/01/ae13_Ernst_Alphen.pdf>. Acesso em: 2 jun. 2014.

BALEIRO, Zeca. Vida é um Souvenir Made in Hong Kong. Goiânia: Ed. UFG, 2010.

BALEIRO, Zeca. Maldição. Disponível em: <http://www.vagalume.com.br/zeca-baleiro/maldicao.html>. Acesso em 13 out. 2014.

BISHOP, Claire. Artificial Hells: Participatory Arte and the politics of Spectadorchip. New York: Verso, 2012.

CASSIRER, Ernst. Antropologia filosófica: ensaio sobre o homem. São Paulo: Mestre Jou, 1977.

CLARK, Ligia. Livro-obra. Nós somos os propositores. Disponível em: <http://www.lygiaclark.org.br/arquivo_detPT.asp?idarquivo=25>. Acesso em 21 abr. 2014.

COSTA, Fabíola C. B. O olho que se faz olhar: espaço estético no contexto escolar. Florianópolis: Núcleo de Publicações, 2013.

DAWKINS, Richard. O gene egoísta. Belo Horizonte: Itatiaia, 2001.

DELEUZE, Gilles; GUATTARI, Félix. O que é a Filosofia? Rio de Janeiro: Ed.34, 1992.

DELEUZE, Gilles Introdução: Rizoma. In: DELEUZE, Gilles; GUATTARI, Félix. Mil platôs: capitalismo e esquizofrenia. v. 1. Rio de Janeiro: Ed.34, 1995 (11-37).

DUCHAMP, Marcel. O ato criador. In: BATTOCK, G. A nova arte. São Paulo: Perspectiva, 1975.

ELIASSON, Olafur. Leer es respirar, es devenir: escritos de Olafur Eliasson. Barcelona: Gustavo Gili, 2012.

FARIAS, Agnaldo. Entre a potência da arte e sua ativação cultural: a curadoria educativa. In: MARTINS, Mirian Celeste, EGAS, Olga e SCHULTZE, Ana. Mediando [con]tatos com arte e cultura. São Paulo: Pós-graduação do Instituto de Artes/Unesp, 2007, p. 66-68 e 87-89.

LARROSA, Jorge. Linguagem e educação depois de Babel. Belo Horizonte, MG: Autêntica, 2004.

MARTINS, Mirian Celeste (Org.). Pensar juntos mediação cultural: [entre]laçando experiências e conceitos. São Paulo: Terracota, 2014.

MARTINS, Mirian Celeste. Mediação: provocações estéticas. São Paulo: Pós-graduação do Instituto de Artes/Unesp, 2007.

MARTINS, Mirian Celeste. Vírus estético. São Paulo: Espaço Pedagógico, 1992 (mimeo).

MARTINS, Mirian Celeste; EGAS, Olga e SHULTZE, Ana Maria (org.) Mediando [con]tatos com arte e cultura. São Paulo: Pós-graduação do Instituto de Artes/Unesp, 2007.

MARTINS, Mirian Celeste; PICOSQUE, Gisa. Mediação cultural para professores andarilhos na cultura. São Paulo: Intermeios, 2012.

PAREYSON, Luigi. Os problemas da estética. São Paulo: Martins Fontes, 1997. 
RANCIÈRE, Jacques. O mestre ignorante: cinco lições sobre a emancipação intelectual. Belo Horizonte, MG: Autêntica, 2010.

\section{Mirian Celeste Martins}

Professora do Programa de Pós-graduação em Educação, Arte e História da Cultura e do Curso de Pedagogia da Universidade Presbiteriana Mackenzie onde coordena os Grupos de pesquisa: Arte na Pedagogia e Mediação Cultural: provocações e mediações estéticas. Professora aposentada do Instituto de Artes/UNESP. Atuou também na Faculdade Santa Marcelina e no Espaço Pedagógico. Foi presidente da Associação de arte-educadores do Estado de São Paulo (1985-1989) e secretária da FAEB - Federação de arte-educadores do Brasil. Dentre suas publicações destaca-se a co-autoria de Teoria e Prática do Ensino de Arte (FTD2011) que faz parte do PNBE-Professor do Ministério da Educação. Co-autora de Por trás da cena, projeto aprovado e financiado pelo Petrobrás Cultural (2010). Tem mestrado em Artes pela Universidade de São Paulo (1992) e doutorado em Educação pela Universidade de São Paulo (1999).

E-mail: mcmart@uol.com.br

Currículo: http://lattes.cnpq.br/7167254305943668 